\title{
MERISTIC AND MORPHOMETRIC VARIATIONS OF BARRED SPINY EEL Macrognathus pancalus POPULATIONS FROM BANGLADESHI FRESHWATERS: AN INSIGHT INTO LANDMARK-BASED TRUSS NETWORK SYSTEM
}

\author{
Md. Sarower-E-Mahfuj ${ }^{1 *}$, Ambia Khatun1, Puja Boidya1, Md. Abdus Samad ${ }^{1,2}$
}

${ }^{1}$ Department of Fisheries and Marine Bioscience, Jessore University of Science and Technology, Jessore-7408, Bangladesh

${ }^{2}$ Department of Socio-cultural Environmental Studies, Division of Environmental Studies, Graduate School of Frontier Sciences, The University of Tokyo, Japan

*Corresponding Author, Email: sa.mahfuz@gmail.com

\section{ARTICLE INFO}

Received: 17 August 2018

Received in revised form: 27 September 2018

Accepted: 5 October 2018

Online first: 25 January 2019

\section{Keywords:}

Meristic

Morphometric

Spiny eel

Truss network

Bangladesh

\section{ABSTRACT}

The present research focuses to examine the meristic and landmark-based morphometric variations of barred spiny eel Macrognathus pancalus from four populations namely Dhakuria beel, Jessore (DBJ); Bohnni boar, Gopalgonj (BBG); the Arial kha river, Madaripur (AKRM) and the Nabaganga river, Jhenidah (NRJ) in Bangladeshi freshwaters. Six meristic counts were compared among four populations and significant differences were observed in number of caudal fin rays and number of pelvic fin rays in all meristic characters. The truss protocol was used in the present study based on six general morphometrics and fifteen truss measurements. Univariate statistics showed that five (standard length $(\mathrm{SL})$, upper jaw length (UJL), lower jaw length (LJL), head depth (HD) and inter orbital (IO)) of six morphometric and eleven truss networks (viz. 2-3, 3-4, 5-6, 6- 7, 7-8, 1-8, 2-8, 3-8, 3-7, 4-7 and 5-7) among fifteen truss measurements differed significantly. Cannonical discriminate function analyses were conducted among samples and the populations were fully intermingled. Pooled withingroup correlation showed morphometric and landmark measurements; the first discriminant function (DF) accounted for 79\%, the second DF accounted for $15.9 \%$ and third DF accounted for $5.1 \%$ of group variability. An euclidian dendrogram was prepared based on morphometric and truss measurements in four populations, where two clusters were mainly formed, in which first cluster formed by NRJ population was fully separated, and the second cluster was formed by two populations of AKRM and DBJ. Additionally, a subcluster BBG was formed with AKRM. On the basis of morphometric and truss measurements, $68.8 \%, 83.6 \%, 55.6 \%$ and $80 \%$ of original grouped cases were correctly classified in NRJ, AKRM, DBJ and BBG, respectively. These results specify the presence of different stocks of fish from four aquatic habitats. This study is highly significant for proper conservation and effective management of $M$. pancalus populations as well as for the scientific community for further research.

Mahfuj, M. S, Khatun, A., Boidya, P., Samad, A. (2019): Meristic and morphometric variations of barred spiny eel Macrognathus pancalus populations from Bangladeshi freshwaters: an insight into landmark-based truss network system. Croatian Journal of Fisheries, 77, 7-18. DOI: 10.2478/cjf-2019-0002. 


\section{INTRODUCTION}

Morphometrics is defined as the study of quantitative analysis such as size and shape of living organisms, which is accomplished by using linear measurements and these studies are essential for understanding the taxonomy as well (Daly, 1985; Park et al., 2013). Therefore, in the same species, morphometric studies are vigorous tools for measuring discreteness (Naeem and Salam, 2005), crucial for demarcation of diverse populations within species in a geographical boundary (Miller et al., 1988), and useful aspects of the fisheries management, conservation and evolutionary context (Turan et al., 2005). Anatomical and physiological features of an organism could be changed by numerous environmental stressors and genetic factors that are responsible for reflecting the phenotypic plasticity through a certain time (Barlow, 1961). Landmark-based technique using morphometrics imposes no restrictions on the direction of variation and localization of shape changes and is highly effective in capturing information about the shape of an organism (Cavalcanti et al., 1999). The truss network of morphometric characters enforces systematic coverage of the form and completely archives the landmark configuration (Nahar et al., 2013; Begum et al., 2013; Liao et al., 2010; Hossain et al., 2010). The truss network system (Strauss and Bookstein, 1982) has been increasingly employed for the purposes of stock identification (Booke, 1981).

Macrognathus pancalus (Hamilton, 1822) is one of the most important freshwater species (locally called Guci baim) and naturally distributed in South-Asia and SouthEast Asian countries (Talwar and Jhingran, 1991). This species grows throughout the country in all types of slow and shallow freshwater bodies (Rahman, 2005). It feeds on bottom debris along with all types of benthic oligocahetes, nematodes and insect larvae (Ali et al., 2004; Serajuddin and Ali, 2005). The fish can hide in the mud and may avoid gear capture. Several males take part in courting one female (Talwar and Jhingran, 1991). M. pancalus population has been deteriorating due to habitat destruction, siltation, inbreeding, fishing pressure, dam construction, parasites, diseases, pollution and other anthropological effects such as pesticides, herbicides and other agrochemicals (DoF, 2012). The extent of occurrence and area of occupancy are much higher than the lower thresholds for any threatened category. Therefore, the species is considered as least concern according to the IUCN Red List (Vishwanath, 2010). Hence, it is highly significant to identify the superior stock of barred spiny eel and increase their sustainable production and extinction. The present research focuses to examine the morphological and meristic variation of $M$. pancalus from four populations occupying Bangladeshi freshwaters using the landmark-based truss network analyses.

\section{MATERIAL AND METHODS}

\section{Sampling}

A total of 153 individuals of $M$. pancalus were collected from four different freshwater sources such as DBJ, BBG, AKRM and NRJ (Fig. 1 and Table 1) and immediately preserved in ice box. The samples were then brought to the laboratory of Department of Fisheries and Marine Bioscience of Jessore University of Science and Technology in Bangladesh for meristic, morphometric and truss network studies. The samples were collected between 2 September and 3 November 2017.

\section{Meristic counts}

Six meristic characters of each individual of $M$. pancalus were counted viz. number of dorsal spine rays (NSOD), number of dorsal soft fin rays (DFR), number of caudal fin rays (CFR), number of anal fin rays (AFR), number of pelvic fin rays (PELFR) and number of black dots on dorsal fins (NOBD).

\section{Imaging of samples and measurement of truss network data}

Firstly, the samples were cleaned in fresh running tap water and placed on a level with transparent white sheet as the background. Then, fin rays were erected and placed

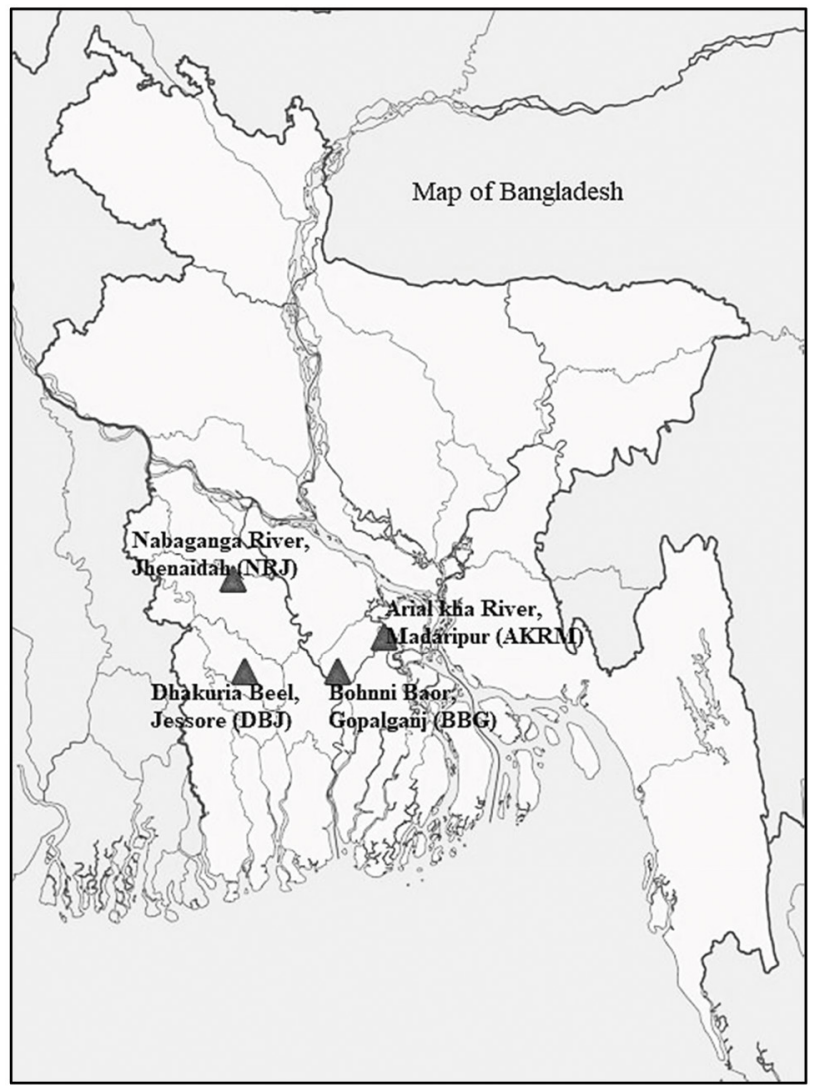

Fig 1. Map of Bangladesh showing collection sites of Macrognathus pancalus from four freshwater sources 
Table 1. Sampling details of Macrognathus pancalus from four freshwater sources in Bangladesh

\begin{tabular}{|c|c|c|c|c|c|}
\hline SI no. & Populations & Abbreviation & Abbreviation & Number of specimens & Mean of SL (SD) \\
\hline 1 & Dhakuria Beel (Jessore) & DBJ & $23.167 \circ \mathrm{N} 89.217 \circ \mathrm{E}$ & 36 & $8.21(1.00)$ \\
\hline 2 & Arial kha River (Madaripur) & AKRM & $22.63 \circ \mathrm{N} 90.53 \circ \mathrm{E}$ & 30 & $8.60(0.65)$ \\
\hline 3 & Nabaganga River (Jhenidah) & NRJ & $23.11 \circ \mathrm{N} 89.38 \circ \mathrm{E}$ & 32 & $10.15(1.33)$ \\
\hline 4 & Bohnni Boar (Gopalgonj) & BBG & $23.20 \circ \mathrm{N} 89.80 \circ \mathrm{E}$ & 55 & $9.68(0.70)$ \\
\hline
\end{tabular}

on the platform to make the origin and insertion points visible. Each individual was labeled with a specific code for proper identification. A Sony Cyber-shot DSC-W730 digital camera (China) was used for capturing digital images with a liner scale that was marked in centimeters (Cadrin and Fridland, 1999). A total of 7 morphometric characters were measured from left to right across the fish body using software platform tpsDig2v 2.1 (Rohlf, 2006) (Table 2).

\section{Description of morphometric characters of M. pancalus fish used for analysis}

The truss protocol in the present study was based on landmark points and truss network was constructed by interconnecting them to form a total of 15 truss measurements (Fig. 2). The extraction of truss distances from the digital images of specimens were conducted using a linear combination of software platform tpsDig2v 2.1 (Rohlf, 2006). Thus, truss distances of fifteen lines connecting these landmarks were generated for each fish to represent the basic shape of the fish (Strauss and
Bookstein, 1982). All measurements were transferred to Microsoft Excel Spreadsheet software 2007 and SPSS 21 software for further analyses (Turan, 1999).

\section{Statistical analyses}

Morphometric distances are continuous variables and therefore appropriate for conventional multivariate analyses. All of the truss measurements were log transformed and tested for normality using the SPSS Statistics 21, and the outliers were removed before further analysis when it was necessary. A multivariate discriminant analysis was used for morphometric data to identify the combination of variables that best separate $M$. pancalus species. Before the analysis, the effects of the size of the dataset were eliminated. In the present study, there were significant linear correlations between all measured characteristics and the total length of fish. To eliminate the variation resulting from morphometric and landmark distances, at first they were standardized according to the formula (Elliott et al., 1995):

Table 2. Description of morphometric characters of $M$. pancalus fish used for analysis

Characters Description

Total length (TL) Distance from the tip of the upper jaw to the end caudal fin ray

Standard length (SL) Distance from the tip of the upper jaw to the end of the vertumn

Body depth (BD) Maximum depth measured from the base of the dorsal spine

Upper jaw length (UJL) Straight line measurement between the snout tip and posterior edge of maxilla

Lower jaw length (LIL) Straight line measurement between the snout tip and posterior edge of mandible

Head depth (HD) Vertical distance at the post position of the operculum

Inter orbital (IO) Distance between dorsal side of both eyes 


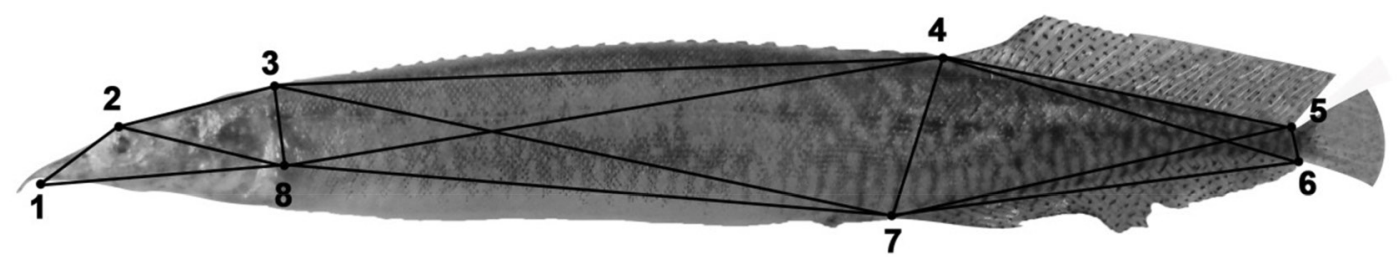

Fig 2. Location of the 8 landmarks for constructing the truss network on fish body illustrated as open circle and morphometric distance measures between the circles as lines

$$
M_{\text {adj }}=M\left(L_{s} / L_{o}\right)^{b}
$$

where $M$ : Original measurement, $M_{\text {adj }}$ : Size adjusted measurement, $L_{o}$ : Total length of fish, and $L_{s}$ : Overall mean of total length for all fish from all samples. Parameter b: was estimated for each character from the observed data as the slope of the regression of $\log M$ on $\log L_{o^{\prime}}$ using all individuals. The efficiency of size adjustment transformations was assessed by testing the significance of the correlation between transformed variable and TL. All meristic characters were compared using the nonparametric Kruskal-Wallis test. The degree of similarity between the samples in overall analysis and the relative importance of each measurement for the separation of the group were evaluated by discriminant function analysis (DFA). Population centroids with 95\% confidence ellipses derived from the DFA were used to visualize relationships among individuals of all groups. A dendrogram of four populations based on the morphometric and truss distance data was drawn by the unweight pair group mathematic averages (UPGMA). Univariate analysis of variance (ANOVA) was carried out to test the significance of morphological differences. All statistical analyses were done using SPSS 21 (SPSS, Chicago, IL, USA).

\section{RESULTS}

\section{Meristic counts}

Meristic counts of all samples ranged from 18-29 for NSOD, 30-44 for DFR, 8-14 for CFR, 30-48 for AFR, 8-17 for PELFR and 3 for NOBD. Meristic counts were compared among four populations viz. DBJ, BBG, AKRM and NRJ. Only significant differences were observed in CFR and PELFR (Kruskal-Wallis test; ${ }^{*} p<0.05, * * p<0.01$, $* * * p<0.001$ ) (Table 3).

\section{Morphometric and truss networks}

The strength of the allometric formula was justified and standardized using correlation of TL with remaining adjusted characters; that is why later the TL was curtailed in further analysis. After the allometric transformation, the correlation results revealed that all of the morphometric and truss measurements showed significant correlation with $\mathrm{TL}$, confirming that the size effect was removed from the data.

Univariate statistics (ANOVA) showed that five (standard length (SL), upper jaw length (UJL), lower jaw length (LJL), head depth (HD) and inter orbital (IO)) of six morphometric

Table 3. Comparison of the meristic characters of $M$. pancalus collected from four different freshwater sources in Bangladesh (DBJ: Dhakuria Beel, Jessore; AKRM: Arial Kha River, Madaripur; NRJ: Nabaganga River, Jhenidah and BBG: Bohnni Boar, Gopalgonj)

\begin{tabular}{|c|c|c|c|c|c|c|}
\hline \multirow{2}{*}{$\begin{array}{c}\text { Meristic } \\
\text { characters }\end{array}$} & \multicolumn{4}{|c|}{ Name of Stocks - (Minimum-Maximum) } & \multirow{2}{*}{$\begin{array}{l}\text { Kruskal Wallis } \\
\text { Test (H-value) }\end{array}$} & \multirow{2}{*}{ Significance } \\
\hline & NRJ & AKRM & DBJ & BBG & & \\
\hline NSOD & $23-26$ & $20-29$ & $18-29$ & $18-28$ & 6.924 & 0.74 \\
\hline DFR & $30-40$ & $30-41$ & $30-44$ & $30-42$ & 4.135 & 0.247 \\
\hline CFR & $10-12$ & $8-14$ & $7-12$ & $8-12$ & 9.234 & $0.026^{*}$ \\
\hline AFR & $30-44$ & $31-48$ & $30-46$ & $36-48$ & 2.946 & 0.400 \\
\hline PELFR & $10-16$ & $8-16$ & $8-15$ & $9-17$ & 25.956 & $0.000^{* * *}$ \\
\hline NOBD & 3 & 3 & 3 & 3 & 0.000 & 1.000 \\
\hline
\end{tabular}


Table 4. Univariate statistics (ANOVA) testing differences among samples from fifteen truss measurements and six morphometric measurements of $M$. pancalus populations from four freshwater sources of Bangladesh. Characters are described in Table 2. $* p<0.05, * * p<0.01, * * * p<0.001$.

\begin{tabular}{|c|c|c|c|c|c|}
\hline Measurements & Wilks' Lambda & $\mathrm{F}$ & df1 & $\mathrm{df} 2$ & Significance \\
\hline SL & 0.870 & 7.390 & 3 & 148 & $0.000^{* * *}$ \\
\hline $\mathrm{BD}$ & 0.975 & 1.251 & 3 & 148 & 0.293 \\
\hline UJL & 0.727 & 18.506 & 3 & 148 & $0.000^{* * *}$ \\
\hline LJL & 0.818 & 10.977 & 3 & 148 & $0.000^{* * *}$ \\
\hline HD & 0.946 & 2.806 & 3 & 148 & $0.042^{*}$ \\
\hline 10 & 0.935 & 3.417 & 3 & 148 & $0.019^{*}$ \\
\hline $1-2$ & 0.969 & 1.597 & 3 & 148 & 0.193 \\
\hline $2-3$ & 0.927 & 3.875 & 3 & 148 & $0.011^{*}$ \\
\hline $3-4$ & 0.942 & 3.041 & 3 & 148 & $0.031^{*}$ \\
\hline $4-5$ & 0.957 & 2.226 & 3 & 148 & 0.088 \\
\hline $5-6$ & 0.909 & 4.916 & 3 & 148 & $0.003^{* *}$ \\
\hline $6-7$ & 0.608 & 31.848 & 3 & 148 & $0.000^{* * *}$ \\
\hline $7-8$ & 0.794 & 12.816 & 3 & 148 & $0.000^{* * *}$ \\
\hline $1-8$ & 0.870 & 7.403 & 3 & 148 & $0.000^{* * *}$ \\
\hline $2-8$ & 0.870 & 7.371 & 3 & 148 & $0.000^{* * *}$ \\
\hline $3-8$ & 0.938 & 3.249 & 3 & 148 & $0.024^{*}$ \\
\hline $3-7$ & 0.890 & 6.111 & 3 & 148 & $0.001^{* *}$ \\
\hline $4-6$ & 0.964 & 1.858 & 3 & 148 & 0.139 \\
\hline $4-7$ & 0.895 & 5.760 & 3 & 148 & $0.001^{* *}$ \\
\hline $4-8$ & 0.962 & 1.972 & 3 & 148 & 0.121 \\
\hline $5-7$ & 0.605 & 32.176 & 3 & 148 & $0.000^{* * *}$ \\
\hline
\end{tabular}


Table 5. Pooled within-group correlations between discriminating variables and discriminant functions (DFs; variables ordered by size of correlation within function, *denotes the largest correlation between each variable and DFs)

\begin{tabular}{|c|c|c|c|}
\hline Measurements & DF1 (79\%) & DF2 (15.9\%) & DF3 (5.1\%) \\
\hline $5-7$ & $-0.563^{*}$ & 0.039 & 0.063 \\
\hline $6-7$ & $-0.560^{*}$ & -0.025 & -0.149 \\
\hline UJL & $0.408^{*}$ & 0.237 & -0.276 \\
\hline $7-8$ & $0.342^{*}$ & 0.197 & 0.164 \\
\hline $2-3$ & $0.193^{*}$ & 0.066 & 0.015 \\
\hline $3-8$ & $0.171^{*}$ & -0.106 & 0.091 \\
\hline LJL & 0.164 & $0.624^{*}$ & -0.226 \\
\hline SL & 0.089 & $0.555^{*}$ & 0.227 \\
\hline $3-4$ & -0.054 & $0.367^{*}$ & -0.039 \\
\hline $1-8$ & 0.217 & $0.357^{*}$ & -0.087 \\
\hline $4-7$ & -0.191 & $0.318^{*}$ & -0.059 \\
\hline $2-8$ & 0.237 & $0.290^{*}$ & 0.000 \\
\hline $1-2$ & -0.017 & $0.278^{*}$ & 0.012 \\
\hline $4-5$ & -0.100 & $-0.233^{*}$ & 0.128 \\
\hline$B D$ & -0.026 & $0.211^{*}$ & -0.206 \\
\hline $5-6$ & 0.186 & -0.046 & $0.460^{*}$ \\
\hline 10 & 0.094 & 0.254 & $0.431^{*}$ \\
\hline$H D$ & -0.126 & 0.160 & $0.319^{*}$ \\
\hline $4-8$ & 0.094 & 0.177 & $-0.260^{*}$ \\
\hline $3-7$ & 0.236 & 0.067 & $0.248^{*}$ \\
\hline $4-6$ & -0.122 & -0.079 & $0.185^{*}$ \\
\hline
\end{tabular}


and $11(2-3,3-4,5-6,6-7,7-8,1-8,2-8,3-8,3-7,4-7$ and $5-7)$ of the 15 truss measurements differed considerably to a varying degree $\left({ }^{*} p<0.05,{ }^{* *} p<0.01,{ }^{* * *} p<0.001\right)$ among samples (Table 4$)$.

The discriminant function analyses (DFA) produced three DFs $\left(1^{\text {st }}, 2^{\text {nd }}\right.$ and $3^{\text {rd }}$ DFs $)$ for both morphometric and truss measurements. For morphometric and truss measurements, the $1^{\text {st }} D F$ accounted for $79 \%$, the $2^{\text {nd }} D F$ accounted for $15.9 \%$ and $3^{\text {rd }}$ DF $5.1 \%$ of among-group variability, and they explained $100 \%$ of the total among- group variability (Table 5). Pooled within-group correlations among discriminant variables and DFs revealed that, among the six morphometric measurements, upper jaw length (UJL) dominantly contributed to the $1^{\text {st }} \mathrm{DF}$, the three measurements of lower jaw length (LJL), standard length (SL) and body depth (BD) contributed to the $2^{\text {nd }}$ $\mathrm{DF}$, and the remaining two measurements of inter orbital (IO) and head depth (HD), respectively, contributed to the $3^{\text {rd }}$ DF (Table 5). Among the fifteen truss measurements, five measurements $(5-7,6-7,7-8,2-3$ and $3-8)$ dominantly

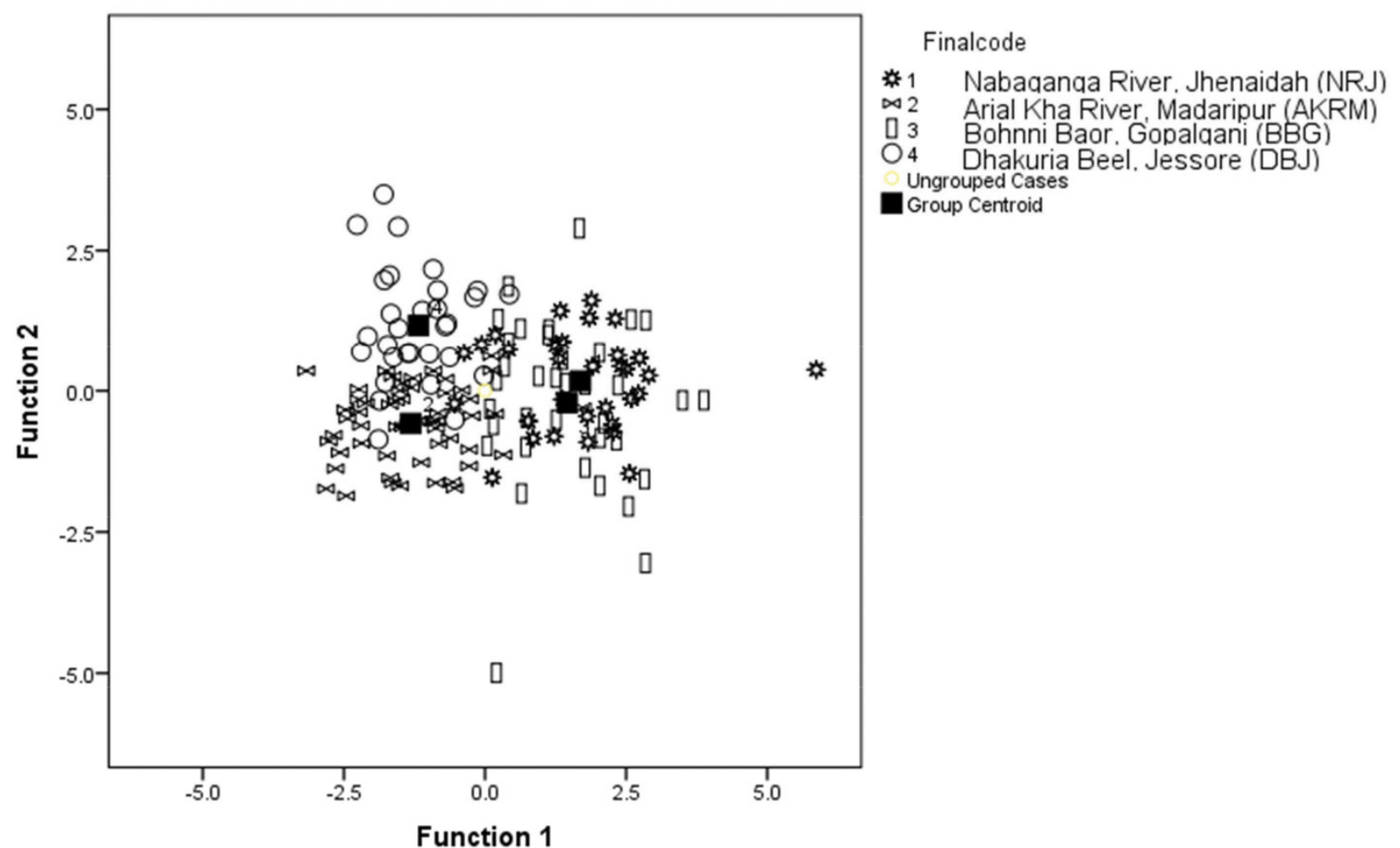

Fig 3. Sample centroids of the discriminant function scores based on general morphometric and truss measurements of Macrognathus pancalus populations from four Bangladeshi freshwaters

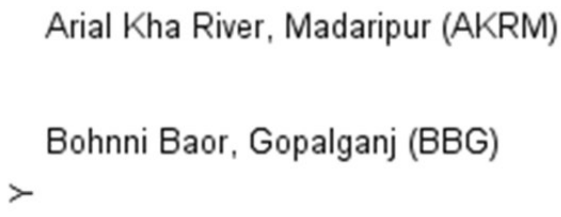

Dhakuria Beel, Jessore (DBJ)

Nabaganga River, Jhenaidah (NRJ)
Rescaled Distance Cluster Combine

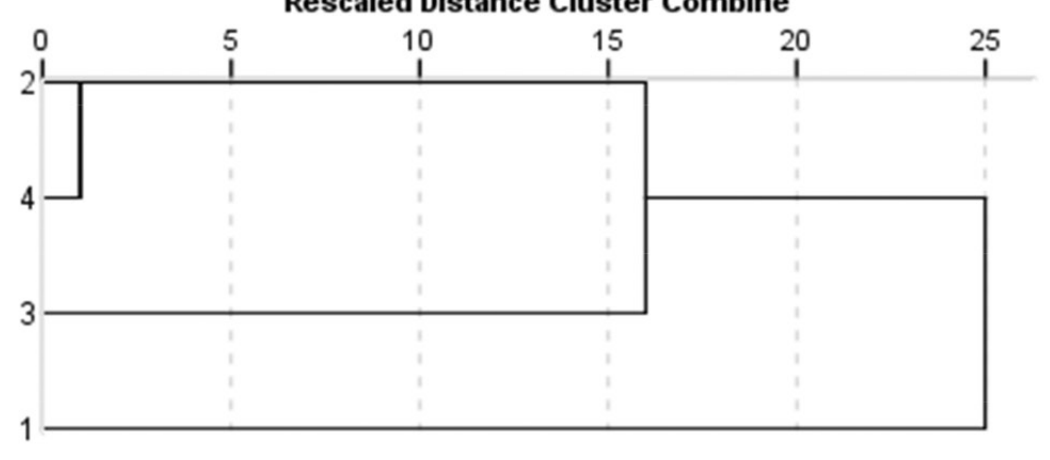

Fig 4. Dendrogram based on morphometric and truss distances of Macrognathus pancalus populations from four different freshwater sources namely Dhakuria Beel, Jessore (DBJ); Arial Kha River, Madaripur (AKRM); Nabaganga River, Jhenidah (NRJ); (KRJ) Bohnni baor, Gopalgonj (BBG) in Bangladesh 
Table 6. Correct classifications of individuals M. pancalus collected from four different freshwater sources (NRJ, AKRM, DBJ and BBG) from Bangladesh

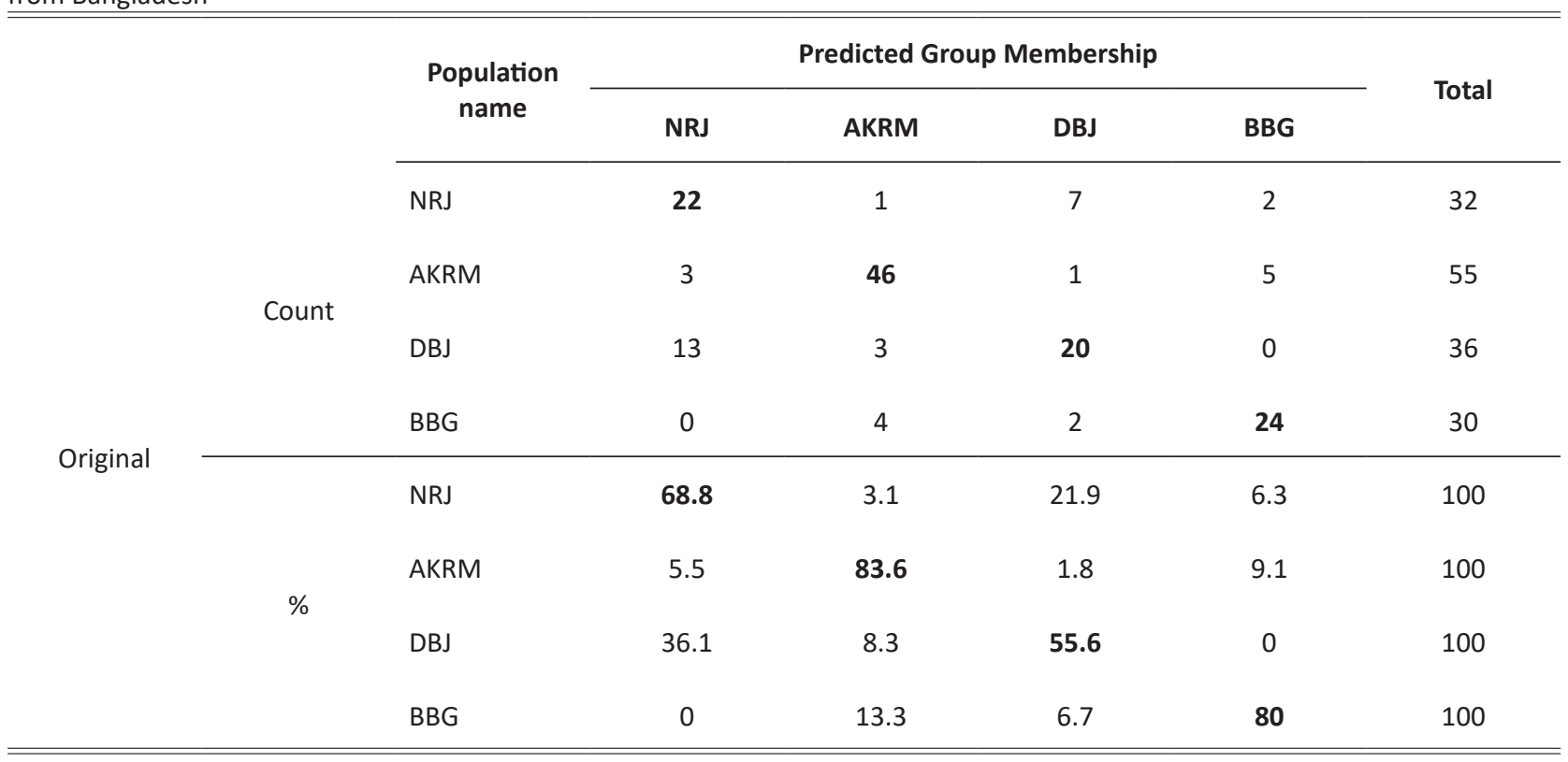

contributed to the $1^{\text {st }}$ DF, six measurements $(3-4,1-8$, 4-7, 2-8, 1-2 and 4-5) contributed to the $2^{\text {nd }}$ DF and the remaining four measurements $(5-6,4-8,3-7$ and 4-6) contributed to the $3^{\text {rd }}$ DF (Table 5).

Plotting all discriminant function analyses (DFA) showed a clear overlapping among the populations for both morphometric and truss measurements. In both morphometric and truss measurements, the stocks are intermingled among each stock in the discriminant space (Fig. 3) with high proportion of overlapping to a varying degree among four stocks. This finding suggested that there was intermingling among four populations such as DBJ, AKRM, NRJ and BBG. A Euclidian dendrogram was based on the morphometric and truss measurement for four populations of NRJ, AKRM, DBJ and BBG. Two clusters were formed in Euclidian dendrogram; 1st cluster was formed by NRJ population and was fully separated, and 2nd cluster was formed by two subclusters of AKRM and DBJ. Additionally, a subcluster of BBG added with AKRM (Fig. 4).

A correct classification of individuals into their original population varied $100 \%$ in four populations by discriminant analysis and $100 \%$ of individual group cases could be classified in their correct a priori grouping (Table 6). $100 \%$ contribution in original classification of the individuals of NRJ, AKRM, DBJ and BBG populations were not found and the individuals were mixed with other populations. But overall in original classification, $72 \%$ of individuals were correctly classified. This finding suggested that there was intermingling among populations and the populations were not fully separated. On the basis of morphometric measurements, $68.8 \%, 83.6 \%, 55.6 \%$ and $80 \%$ of original grouped cases were correctly classified in case of NRJ, AKRM, DBJ and BBG (Table 6).

\section{DISCUSSION}

Both meristic counts and truss morphometric studies exposed main heterogeneity among the $M$. pancalus populations, among four populations. However, four populations are geographically separated and remarkably the populations originated from different sources.

Moreover, there might be no chances of migration of individuals among four populations since the geographic position of two rivers are quite different (i.e. NRJ and AKRM) as well as the location of BBG and DBJ. All samples in four populations exhibited high phenotypic variation among each other indicating that there may not be any chances of immigration and emigration. Similar research was reported by Plamoottil and Abraham (2014) in Macrognathus albus where the meristic traits were as follows: 26-30 numbers for dorsal fin spines, 14-16 numbers for pectoral fin rays, 11 for caudal fin rays, 3 for anal fin spines.

Parallel research was also conducted by Sultana et al. (2017) on M. pancalus species resembling 19-39 numbers for dorsal fin spines, 11-18 numbers for caudal fin rays, 29-52 numbers for anal fin rays. Consistent results were also reported by Roberts (1980) on Macrognathus species of meristic characters of number of dorsal fin spines: 14-22 in $M$. aculeatus, $16-23$ in $M$. aral and 13-19 in $M$. siamensis. In a separate study, significant differences were observed in dorsal and anal soft fin rays, even though significant differences were not found in remaining meristic characters of Mesopotamian Mastacembelus mastacembelus populations among three populations of the Karakay reservoir, the Tohma stream and the Tigris river (Çakmak and Alp, 2010). Such causes of meristic variation might occur due to abiotic factors, 
for instance water $\mathrm{pH}$, water quality, water temperature (Treer, 1993), day degrees (Tåning, 1952), heritability (Tave, 1984), high salinity and lower oxygen level, and developmental rate (Barlow, 1961). Generally longer developmental rates enhance more amounts in meristic configurations in an organism. Significant deviations were found in the head region and posterior part of the body of well-fed and feed deprived Oncorhynchus mykiss and O. tshawytscha (Currens et al., 1989). Related findings were also detected in Clarius batracus population (Miyan et al., 2016), Channa punctatus population (Khan et al., 2013) and Heteropneustes fossilis population (Rahman et al., 2014). Generally, fishes inhabiting turbid water conditions are living in suspended solid medium; they ultimately modify in body physiology as well as reduce in eye diameter and inter-orbital distance (Moore, 1950). Generally, fish and aquatic vertebrates exert phenotypic plasticity because they adapt quickly through modifying their physiology and behavior to environmental changes. Moreover, phenotypic plasticity in morphometric traits may often be adaptive (Robinson and Parsons, 2002). Moreover, phenotypical plasticity and adaptations completely or partially relied on external forces from the environment (He et al., 2013). Other environmental influences may involve heterochrony, changes in the relative timing of developmental events (Meyer, 1987) such as switches between growth and development (Martin, 1949). Although environmental influences on morphometric characteristics have not been well studied in this work, a number of influential factors were identified by Swain et al. (2005). Haas et al. (2010) found that the physical characteristics of habitats drive changes in the morphological attributes of native fish populations. However, external morphology of fish is especially dependent on environmental conditions during early life history stages (Ryman et al., 1984; Cheverud, 1988). Morphometric studies are able to identify differences between fish populations and are helpful tools for the discrimination of fish populations (Bailey, 1997; SaboridoRey and Nedreaas, 2000; Palma and Andrade, 2002). Besides, morphometric measurements, combined with image analysis, represent a method for improving fish stock structures (Bailey, 1997). Nevertheless, researchers have identified the real phenomena of morphological and physiological alterations (i.e. genetic factors like natural selection, epigenetic inheritance) (Murta, 2000; Pigliucci, 2001), and effective population size and inbreeding (He et al., 2013). Furthermore the populations in this study may have originated from different ancestors. These explanations are highly matched with the previous research accomplished in Labeo calbasu (Hossain et al., 2010), in Channa punctatus (Khan et al., 2013), in Cirrhinus cirrhosus (Gain et al., 2017), in Labeo bata (Mahfuj et al., 2017) and in Labeo ariza (Ahammad et al., 2018). Truss linkage arrangements are a dominant tool for fish stock identification and therefore truss network measurements were employed in this experiment (Turan et al., 2004).
Consequently, outputs of (DFA) in both morphometric and truss distances recommend very high aggregation among populations. However, plotting discriminant function DF1, DF2 and DF3 showed a clear aggregation among all the stocks for both morphometric and landmark measurements. All populations were undoubtedly intermingled from each stock in the discriminant space. For morphological and truss measurements first, second and third (DF) accounted $79 \%, 15.9 \%$ and $5.1 \%$ of amonggroup variability, respectively. It explained and proved that first DF was more informative than the second and third DF in explaining differences among the stocks. The second and third DF is therefore less informative than the first DF in elucidating changes among stocks. This information suggested that there was high intermingling among populations and individuals were highly inter-mixed. It indicated that the discriminant examination was relevant as an effective method in identifying populations, strains and subspecies which have been closely related. The authors recommended that procedure of more than one technique and evaluation among them could upsurge the probability for decorously cataloguing or differentiating the populations.

\section{CONCLUSION}

Meristic and truss-based morphometry study will be helpful in order to expand the excellence of stock documentation research. Even though, numerous methods are frequently studied for stock identification, meristic and truss morphometry is a cost-effective technique for enhancing fisheries management. Reliable evidence and investigation of stock structure are essential for breeding, exploitation, habitat restoration and conservation. Further study particularly on genetic studies and investigations of the influences of environmental subtleties are desirable for conservation of selected stocks to overlay the mode of saving this leastconcern species from quick disappearance.

\section{SAŽETAK}

\section{MERISTIČKE I MORFOMETRIJSKE VARIJACIJE U POPULACIJAMA PRUGASTE BODLIIKAVE JEG- ULJE Macrognathus pancalus SLATKOVODNIH VODA BANGLADEŠA: UVID U SUSTAV VEZANE MREŽE}

Istraživanje se temelji na analizi merističkih $\mathrm{i}$ orijentirbaziranih morfometrijskih varijacija četiri populacije prugaste bodljikave jegulje Macrognathus pancalus (Dhakuria, Jessore - DBJ; Bohnni, Gopalgonj - BBG; rijeka Arial kha, Madaripur - AKRM; rijeka Nabaganga, Jhenidah - NRJ) u slatkovodnim vodama Bangladeša. Uspoređeno je 
šest merističkih mjera unutar četiri populacije, a značajne razlike su zabilježene u broju žbica repne peraje i broju žbica trbušne peraje kod svih merističkih pokazatelja. U radu je korišten protokol vezane mreže na temelju šest općenitih, morfometrijskih, i petnaest vezanih mjera. Jednosmjerna analiza varijanci ukazala je značajnu razliku između pet morfometrijskih (standardna dužina (SL), duljina gornje čeljusti (UJL), duljina donje čeljusti (LJL), dubina glave (HD) i interorbitalna duljina (IO)) i jedanaest mjera vezane mreže (tj. 2-3, 3-4, 5-6, 6-7, 7-8, 1-8, 2-8, 3-8, 3-7, 4-7 i 5-7). Provedene su i analize funkcije kanoničke diskriminacije koje su ukazale na potpunu isprepletenost populacija. Zbirna korelacija unutar grupe ukazala je na varijabilnost skupina morfometrijskih i orijentir-baziranih mjerenja: prva diskriminantna funkcija (DF) iznosila je $79 \%$, druga DF $15,9 \%$, a treća DF 5,1\% varijabilnosti skupina. Euklidski dendrogram pripremljen je na temelju morfometrijskih $\mathrm{i}$ vezanih mjerenja kod četiri populacije jegulja. Formirana su, uglavnom, dva klastera, kod kojih je prvi, nastao od NRJ populacije, potpuno odvojen, a drugi klaster je formiran $s$ dvije populacije AKRM i DBJ. Dodatno, formiran je podklaster BBG s AKRM-om. Na temelju morfometrijskih i vezanih mjerenja, $68,8 \%, 83,6 \%, 55,6 \%$ i $80 \%$ originalnih grupiranih slučajeva ispravno je klasificirano u NRJ, AKRM, DBJ odnosno u BBG. Ovi rezultati ukazuju na prisutnost riba različitog podrijetla u četiri vodena staništa. Ovo istraživanje je značajno za pravilno očuvanje i učinkovito upravljanje populacijama $M$. pancalus kao i za daljnja istraživanja znanstvene zajednice.

Ključne riječi: meristika, morfometrija, bodljikava jegulja, metoda vezane mreže, Bangladeš

\section{REFERENCES}

Ali, M. Y., Sahm, G. M., Mannan, M. A., Rahman, M. M., Sabbir, W., Murshida, A. (2004): Fish species availability observed in the fish landing centers of Khulna district in Bangladesh. Journal of Biological Sciences, 4, 5, 575580 .

Ahammad, A. K. S., Ahmed, M. B. U., Akhter, S., Hossain, M. K. (2018): Landmark-based morphometric and meristic analysis in response to characterize the wild Bhagna, Labeo ariza populations for its conservation. Journal of the Bangladesh Agricultural University, 16, 1, 164-170.

Bailey, K. M. (1997): Structural dynamics and ecology of flatfish populations. Journal of Sea Research, 37, 3, 269-280.

Barlow, G. W. (1961): Causes and significance of morphological variation in fishes. Systematic Zoology, 10, 3, 105-117.

Begum, A., Khan, M. M. R., Nahar, K., Minar, M. H., Sultana, N., Khan, M. G. Q. (2013): Morphological and genetic variations in wild and hatchery populations of gonia (Labeo gonius, Hamilton) using truss Measurement and allozyme markers. International Journal of Life Sciences Biotechnology and Pharma Research, 2, 2, 204-221.

Booke, H. E. (1981): The conundrum of the stock concept - are nature and nurture definable in fishery science. Canadian Journal of Fisheries and Aquatic Sciences, 38, 12, 1479-1480.

Cadrin, S. X., Friedland, K. D. (1999): The utility of image processing techniques for morphometric analysis and stock identification. Fisheries Research, 43, 1, 129-139.

Çakmak, E., Alp, A. (2010): Morphological differences among the Mesopotamian spiny eel, Mastacembelus mastacembelus (Banks \& Solander 1794) populations. Turkish Journal of Fisheries and Aquatic Sciences, 10, 1, 87-92.

Cavalcanti, M. J., Monteiro, L. R., Lopes, P. R. (1999): Landmark-based morphometric analysis in selected species of serranid fishes (Perciformes: Teleostei). Zoological studies Taipei, 38, 3, 287-294.

Cheverud, J. M. (1988): A comparison of genetic and phenotypic correlations. Evolution, 958-968.

Currens, K. P., Sharpe, C. S., Hjort, R., Schreck, C. B., Li, H. W. (1989): Effects of different feeding regimes on the morphometrics of chinook salmon (Oncorhynchus tshawytscha) and rainbow trout (O. mykiss). Copeia, 689-695.

Daly, H. V. (1985): Insect morphometrics. Annual review of entomology, 30, 1, 415-438.

DoF. (2012): Fishery statistical yearbook of Bangladesh. Fisheries Resources Survey System. Department of Fisheries, Ministry of Fisheries and Livestock, Government of the Peoples, Republic of Bangladesh, Dhaka.

Elliott N. G., Haskard, K. Koslow, J. A. (1995): Morphometric analysis of orange roughy (Hoplostethus atlanticus) off the continental slope of southern Australia. Journal of Fish Biology, 46, 202-220.

Gain, D., Mahfuj, M. S., Huq, K. A, Islam, S. S., Minar, M. H., Goutham-Bharathi, M. P., Das, S. K. (2017): Landmark-based morphometric and meristic variations of endangered mrigal Carp, Cirrhinus cirrhosus (Bloch 1795) from wild and hatchery stocks. Sains Malaysiana, 46, 5, 695-702.

Haas, T. C., Blum, M. J., Heins, D. C. (2010): Morphological responses of a stream fish to water impoundment. Biology letters, 6, 6, 803-806.

Hamilton, F. (1822): An account of the fishes found in the river Ganges and its branches. Printed for A. Constable and company.

He, Y., Li, R., Wang, J., Blanchet, S., Lek, S. (2013): Morphological variation among wild populations of Chinese rare minnow (Gobiocypris rarus): Deciphering the role of evolutionary processes. Zoological science, 30, 6, 475-483.

Hossain, M. A. R., Nahiduzzaman, M., Saha, D., Khanam, M. U. H., Alam, M. S. (2010): Landmarkbased morphometric and meristic variations of the endangered Carp, Kalibaus (Labeo calbasu) from stocks 
of two isolated rivers, the Jamuna and Halda, and a hatchery. Zoological Studies, 49, 4, 556-563.

Khan, M. A., Miyan, K., Khan, S. (2013): Morphometric variation of snakehead fish, Channa punctatus, populations from three Indian rivers. Journal of Applied Ichthyology, 29, 3, 637-642.

Liao, C. H., Liu, T. Y., Hung, C. Y. (2010): Morphometric variation between the swordtip (Photololigo edulis) and mitre (P. chinensis) squids in the waters off Taiwan. Journal of Marine Science and Technology, 18, 3, 405412.

Mahfuj, M. S, Ashraful, A., Parvez, I., Minar, M. H., Samad, A. (2017): Morphological variations of Labeo bata populations (Teleostei: Cyprinidae) in six rivers of Bangladesh: a landmark-morphometric contribution. Iranian Journal of Ichthyology, 4, 3, 270-280.

Martin, W. R. (1949): The mechanism of environmental control of body form in fishes. University of Toronto.

Meyer, A. (1987): Phenotypic plasticity and heterochrony in Cichlasoma managuense (Pisces, Cichlidae) and their implications for speciation in cichlid fishes. Evolution, 41, 6, 1357-1369.

Miller, S. L., Gregg, M. A., Kuritsubo, A. R., Combs, S. M., Murdock, M. K., Nilsson, J. A., Botzler, R. G. (1988): Morphometric variation in tundra swans: relationships among sex and age classes. Condor, 802-815.

Moore, G. A. (1950): The cutaneous sense organs of barbeled minnows adapted to life in the muddy waters of the Great Plains region. Transactions of the American Microscopical Society, 69, 1, 69-95.

Murta, A. G. (2000): Morphological variation of horse mackerel (Trachurus trachurus) in the Iberian and North African Atlantic: implications for stock identification. ICES Journal of Marine Science, 57, 4, 1240-1248.

Miyan, K., Khan, M. A., Patel, D. K., Khan, S., Ansari, N. G. (2016): Truss morphometry and otolith microchemistry reveal stock discrimination in Clarias batrachus (Linnaeus, 1758) inhabiting the Gangetic river system. Fisheries research, 173, 294-302.

Naeem, M., Salam, A. (2005): Morphometric study of fresh water bighead carp Aristichthys nobilis from Pakistan in relation to body size. Pakistan Journal of Biological Sciences, 8, 5, 759-762.

Nahar, K., Hossain, M., Begum, A., Sultana, N., Khan, M. G. Q. (2013): Genetic structure of endangered bata (Labeo bata, Hamilton) inferred from landmark based morphometric and meristic measurements and allozyme markers. International Research Journal of Pharmaceutical and Applied Sciences, 3, 5, 145-160.

Palma, J., Andrade, J. P. (2002): Morphological study of Diplodus sargus, Diplodus puntazzo, and Lithognathus mormyrus (Sparidae) in the Eastern Atlantic and Mediterranean Sea. Fisheries Research, 57(1), 1-8.

Park, P. J., Aguirre, W. E., Spikes, D. A., Miyazaki, J. M. (2013): Landmark-based geometric morphometrics - What fish shapes can tell us about fish evolution. Proceedings of Association of Biological Laboratory
Education, 34, 361-371.

Plamoottil, M., Abraham, N. P. (2014): Macrognathus albus (Order: Synbranchiformes; Family: Mastacembelidae), a new fish species from Kerala, India. International Journal of Pure and Applied Zoology, 2, 2, 100-105.

Pigliucci, M. (2001): Phenotypic Plasticity: Beyond Nature and Nurture Johns Hopkins University Press Baltimore.

Rahman, A. K. A. (2005): Freshwater fishes of Bangladesh, 2nd ed. Dhaka, Bangladesh: Zoological Society of Bangladesh, xviii + 394 .

Rahman, M. M., Sharker, M. R., Sumi, K. R., Alam, M. A., Hossen, M. S. (2014): Landmark-based morphometric and meristic variations of stinging catfish, Heteropneustes fossilis (Bloch) among three isolated stocks, the Old Brahmaputra River and the Tanguar haor and a hatchery. International Journal of Fisheries and Aquatic Studies, 1, 3, 163-170.

Roberts, T. R. (1980): A revision of the Asian mastacembelid fish genus Macrognathus. Copeia, 385-391.

Robinson, B. W., Parsons, K. J. (2002): Changing times, spaces, and faces: tests and implications of adaptive morphological plasticity in the fishes of northern postglacial lakes. Canadian Journal of Fisheries and Aquatic Sciences, 59, 11, 1819-1833.

Rohlf, F. J. (2006): tpsDig2.1. Stony Brook, NY: Department of Ecology and Evolution, State University of New York.

Ryman, N., Lagercrantz, U., Andersson, L., Chakraborty, R., Rosenberg, R. (1984): Lack of correspondence between genetic and morphologic variability patterns in Atlantic herring (Clupea harengus). Heredity, 53, 3, 687-704.

Saborido-Rey, F., Nedreaas, K. H. (2000): Geographic variation of Sebastes mentella in the Northeast Arctic derived from a morphometric approach. ICES Journal of Marine Science, 57, 4, 965-975.

Serajuddin, M., Ali, R. (2005): Food and feeding habits of striped spiny eel, Macrognathus pancalus (Hamilton). Indian Journal of Fisheries, 52, 1, 81-86.

Strauss, R. E., Bookstein, F. L. (1982): The Truss: Body Form Reconstructions in Morphometrics. Systematic Biology, 31, 2, 113-135.

Swain, D. P., Hutchings, J. A., Foote, C. J. (2005): Environmental and genetic influences on stock identification characters. Stock Identification Methods: Applications in Fishery Science, 45-85.

Sultana, S., Nahar, K., Bir, J., Kabiraj, M., Khan, M. N. (2017): A quick view on biology of near threatened peacock eel (Macrognathus aculeatus) in Khulna region of Bangladesh. American Journal of Zoological Research, 5, 2, 38-46.

Tave, D. (1984): Genetics of dorsal fin ray number in the guppy, Poecilia reticulata. Copeia, 140-144.

Talwar, P. K., Jhingran, A. G. (1991): Inland fisheries of India and adjacent countries, Vol. 2.

Tåning, Å. V. (1952): Experimental study of meristic characters in fishes. Biological Reviews, 27, 2, 169-193.

Treer, T. (1993): The use of meristic and morphometric characteristics in differentiation of fish populations. 
Croatian Journal of Fisheries: Ribarstvo, 48, 1, 13-27.

Turan, C. (1999): A note on the examination of morphometric differentiation among fish populations: the truss system. Turkish Journal of Zoology, 23, 3, 259264.

Turan, C., Ergüden, D., Gürlek, M., Başusta, N., Turan, F. (2004): Morphometric structuring of the anchovy (Engraulis encrasicolus L.) in the Black, Aegean and Northeastern Mediterranean Seas. Turkish Journal of Veterinary and Animal Sciences, 28, 5, 865-871.
Turan, C., Yalçin, S., Turan, F., Okur, E., Akyurt, I. (2005): Morphometric comparisons of African catfish, Clarias gariepinus populations in Turkey. Folia Zoologica, 54, 1/2, 165.

Vishwanath, W. (2010): Macrognathus pancalus. The IUCN Red List of Threatened Species 2010: e.T166542A6232710. http://dx.doi.org/10.2305/IUCN. UK.2010-4.RLTS. T166542A6232710. en. Downloaded on 17 August 2018. 